\title{
Rethinking Operatic Masculinity: Nicola Tacchinardi's Aria Substitutions and the Heroic Archetype in Early Nineteenth-Century Italy
}

\author{
PARKORN WANGPAIBOONKIT**
}

\begin{abstract}
This article looks at representations of masculinity in Italian operatic performance in the 1820s and 1830s, with a particular focus on the ways in which male characters were transformed through the practice of aria and scene substitutions. Upon his retirement in 1833, the tenor Nicola Tacchinardi chastised musico performers - women who sang male roles - for their unconvincing portrayal of operatic heroes. Rather than complain about their high-lying voices, he chose to criticise these women's feminine appearance and idiosyncratic stage behaviours as unmasculine. Tacchinardi's criteria for gender performance, then, sidestepped embodied vocality and centred on performer appearance and behaviour in specific narrative situations. My study explores how Tacchinardi and his contemporaries employed aria substitution in heroic roles as a means for plot substitution, forgoing arias of dramatic stasis for dynamic scenes that showcase decisive action and augmented narrative significance. In this pre-Duprez milieu, before the onset of predetermined physiology in operatic discourse, male singers across the 1820 s achieved an explicitly masculine selfdefinition not through voice, but as masters of textual control. Aria substitutions in the operas La Sacerdotessa d'Irminsul, La donna del lago and Norma demonstrate how singers established the components of masculine-heroic conventions through sensitive consideration of dramaturgy. I stress that the singing voice before 1830 was under-assimilated as an index of gender, and that rethinking the history of the 'rise of the tenor' may be crucial to understanding the history of the vocalic body.
\end{abstract}

What really are conventions? Convention equals a pact, an agreement, a capitulation, it assumes also ceremony, something honest and fair ... But conventions of the theatre are something else altogether. Their ingredients are composed of jealousy, presumptions, intrigue, and ignorance.

Nicola Tacchinardi ${ }^{1}$

Having retired from performance in 1833, the tenor Nicola Tacchinardi penned these words in his treatise on the defects of Italian opera. While the conventions

* Parkorn Wangpaiboonkit, University of California, Berkeley, USA; parkorn@berkeley.edu. I would like to thank James Q. Davies, Heather Hadlock, Gabrielle Lochard, Mary Ann Smart and the anonymous reviewers of this journal for their guidance and feedback.

1 'Cosa sono realmente le convenienze? Convenienza, equivale a patto, convenzione, capitolazione ec: Si prende ancora per cerimonia, cosa onestà od equità ... Ma le convenienze teatrali sono tutt'altra cosa. L'ingredienti che ne formano la composizione sono: l'invidia per il primo, la presunzione, l'intrigo, e l'ignoranza.' Nicola Tacchinardi, Dell'opera in musica sul teatro italiano e de' suoi difetti (Modena, 1955), 61-2. 
he bemoans pertain to various aspects of performance, from posture and gesture to diction and aria substitution, his polemic is far from diplomatic: it targeted the capricious behaviour of musicos (women who performed male roles), a performer category that, along with the prima donna, dominated the operatic stage at the beginning of the nineteenth century. ${ }^{2}$ He recalls, for example, a musico performing in Zingarelli's Giulietta e Romeo. Dressed 'more like a woman than a man', this Romeo refused to carry a sword at her hip because it impaired her movement. When it came to the combat scene, she had to be handed a sword from off-stage, to the amusement of the audience. Another anecdote recalls a musico performing an entrance aria that features her arrival by ship. Displeased with the ship provided for her, the musico decided to enter on foot, climbing over the painted seas. She began her aria while walking on water 'without any embarrassment for the great laughter produced in reaction to this bizarre entrance. ${ }^{3}$ To Tacchinardi, such incidents were far from 'honest and fair', but instead concealed and authorised the whims of the women who failed to satisfy his standard of masculine presentation.

Such a diatribe may be rooted in jealousy: Tacchinardi's own operatic career had been adversely affected by the tension between the musico and the tenor as dramatic masculine archetypes. As Heather Hadlock has shown, three registers of heroic masculinity coexisted on the Italian stage between 1810 and 1830 - castrato, musico and tenor - and during this time, the tenor's place was the most precarious. ${ }^{4}$ With the stark exception of Rossini's celebrated tenor-vehicle Otello, the roles Tacchinardi sang most in his prime were not decisive, masculine heroes, but rather secondary characters - a father, king, or uncle - who served either as mere backdrop or as an unsympathetic impediment to the conventional romance between soprano and musico. ${ }^{5}$

Tacchinardi's treatise considers these breaches of stage decorum by the musico not as trivial, isolated behaviour, but as a categorical reason to reject the musico as a performer of heroic characters:

2 See Heather Hadlock, 'On the Cusp between the Past and the Future: The Mezzo-Soprano Romeo of Bellini's I Capuleti, Opera Quarterly 17 (2001), 399-422.

3 Tacchinardi, Dell'opera in musica sul teatro italiano, 56.

4 Heather Hadlock, 'Women Playing Men in Italian Opera, 1810-1835', in Women's Voices Across Musical Worlds, ed. Jane A. Bernstein (Boston, 2004), 285-307. As a case in point, the 26 December 1821 opening of the carnival season in Venice, Milan and Rome, respectively, presented castrato, musico and tenor in the masculine-heroic lead: at La Fenice, Giovanni Battista Velluti premiered the title role of Mercadante's Andronico; at La Scala, Rosmunda Pisaroni starred in Pucitta's Andromaca; and at Teatro Argentina, Domenico Donzelli premiered Pacini's Cesare in Egitto. The retirements of castrato Giovanni Battista Velluti and contralto Rosmunda Pisaroni around 1830 coincided with the ultimate disappearance of these dramatic types. The career and decline of Pisaroni are detailed in Hadlock, 'Women Playing Men in Italian Opera'. On the decline of castrati, see J.Q. Davies, "Veluti in Speculum": The Twilight of the Castrato', Cambridge Opera Journal 17 (2005), 271-301; and Martha Feldman, 'Shadow Voices, Castrato and Non', in The Castrato: Reflections on Natures and Kinds (Berkeley, 2015), 211-61.

5 Throughout the 1810s, and despite much critical success, Tacchinardi consistently played fathers to either the soprano or musico in operas such as Nicolini's Angelica e Medoro, Rossini's Tancredi and Edoardo e Cristina, and Zingarelli's Giulietta e Romeo. 
We always see the woman who dresses as a man on stage, replacing the alreadyvanished musico [castrato] in the part of lover, as if in jest or masquerade. Never does she assume the character and appearance of a man. Her stride is always of the woman. The fit of her dress and the style of her hair are always that of a lady. Her helmet is worn at an angle in order to show off her lavish curls, which are parted at the front to descend across her cheeks, always in the feminine manner. How could we ever deceive ourselves that this figure represents a conquistador, a fearsome warrior, a husband already a father, a rival for kings and for queens? ${ }^{6}$

For Tacchinardi, to appear 'as a man' on the operatic stage was the standard for masculine performance, a visual criterion rendered unattainable by womanly caprice. The implication of Tacchinardi's complaint is that, once the operatic hero is dissociated from feminine conventions, proper masculinity - honest and fair - will take its rightful place.

It is striking that a tenor's gravest objection to the musico would concern lapses in visual presentation - the way she moves, gestures and dresses - rather than her singing voice. From today's vantage point, the most straightforward argument against the musico as hero would be that her high-lying voice could not possibly index the body of a man. When Tacchinardi was writing, however, the ringing high notes from the chest that, today, typify the Italian heroic tenor had not yet been heard. This was a time before what J.Q. Davies calls 'a new art of "the voice" and its attendant biomedical understanding took hold on operatic discourse, before singing became understood as a 'grainy' expression of an individual's natural interiority. The tenor during Tacchinardi's career could not claim his place in the masculine-heroic roster by privileging the gendered timbral quality of his voice: his singing was more an emitted 'representation' of fixed mimetic states, not an extracted 'presentation' of inner life, a physiological presence from deep within. ${ }^{7}$ To be 'as a man' on stage in the $1820 \mathrm{~s}$, then, was not determined by an ontologically male voice of particular timbre, but rather was an aesthetic register codified in the performer's visual presentation and decisiveness of action.

6 'La donna che in teatro veste da uomo, rimpiazzando nelle parti d'amoroso i già svaniti Musici, la vedremo sempre donna in abito virile, come per ischerzo, o immascherata. Mai ne prende il carattere, e le sembianze. Il camminare è sempre di femmina. Le attillature del vestire son sempre quelle di una donna: Di donna sono parimente le inanellate capigliature. L'elmo portato a mezza testa a guisa di scuffia onde far vedere i grondanti ricci, che scendono sulle gote, e la spartita fronte, sono sempre femminili abbigliature: Come mai c'illuderemo vedendo rappresentare a queste figure, un Conquistatore, un Guerriero tanto temuto, durante tutta la rappresentazionie: Un marito divenuto già Padre: uncompetitore di Regni, e di Regine?' Tacchinardi, Dell'opera in musica sul teatro italiano, 41-2.

7 J.Q. Davies, Romantic Anatomies of Performance (Berkeley, 2014), at 16-18. For an overview of this transition between musico and tenor, see Carolyn Abbate and Roger Parker, 'The Tenor Comes of Age', in A History of Opera (New York, 2015), 215-21. After 1830, musico roles were relegated to sidekicks, such as Maffio Orsini in Donizetti's Lucrezia Borgia. See Hadlock, 'On the Cusp between the Past and the Future'; and Naomi Andre, 'Taming Women's Voices: From Hero to Pageboy', in Voicing Gender: Castrati, Travesti, and the Second Woman in Early Nineteenth-Century Italian Opera (Bloomington and Indianapolis, 2006), 103-28. See also Corinne E. Blackmer and Patricia Juliana Smith, eds., En Travesti: Women, Gender Subversion, Opera (New York, 1995). 
I argue that, at the close of the 1820s, normative conceptions of masculine-heroic performativity were textual and ocular-centric, more than sonic or vocal. As Tacchinardi's complaints suggest, the prototypical heroic lead was not determined by vocal range or register, but by the ways they used their bodies on stage. This is not to say that the body in the voice was invariably sexless, but that, to borrow from Freya Jarman's reading of Barthes, the singing voice before 1830 was underassimilated as an index of gender performance. ${ }^{8}$ Neither the performer's voice nor body were evidently expressive as masculine except as they were inflected and categorised by texts and dramatic situations. In other words, masculine performativity was produced not by gendered vocal timbre, but by a singer's judicious fashioning of character through drama and stage decorum. Furthermore, as my case studies will demonstrate, the tenor voice was not the only site at which fluid and performative versions of stage masculinity were explored. This stance complicates the conventional story of the 'rise of the tenor', which centres on the ascendancy of the chest voice, mythologised by Gilbert Duprez's do di petto in 1837, as a successful bid for the tenor's heroic place in the dramatis personae. ${ }^{9}$ By separating vocal timbre from the performance of masculinity, I explore how the singer achieved explicitly male selfdefinition in this pre-Duprez milieu, not as a voice, but as an author, a master of textual control.

To probe this history, I focus on the practice of aria substitution as a site where singers' decisions about performance material render visible contemporary attitudes about the proper relationship between character and gender. It was common practice throughout the eighteenth and early nineteenth centuries for singers to discard an aria written for a role and to replace it with a number - an existing aria from a different opera, or a new aria composed to order - that better suited their vocal abilities or showcased the persona they wished to project. Some critics vilified this piecemeal, singer-centric approach as a shortcut by singers who were too lazy, self-absorbed, or technically deficient to perform the opera's original music. ${ }^{10}$ However, Hilary Poriss has shown that aria substitution was a standard practice employed even by top-rank

8 Freya Jarman, Queer Voices (New York, 2011), 8-10.

9 John Rosselli offers an account of the tenor's status across the nineteenth century much rooted in their ability to 'carry their chest register up towards high C'; 'The Age of the Tenor' in his Singers of Italian Opera (Cambridge, 1992), 176-201. See also Andre, Voicing Gender, the section 'Men's Voices and Women's Voices', 3-5; Freya Jarman, 'Pitch Fever: The Castrato, the Tenor, and the Question of Masculinity in Nineteenth-Century Opera', in Masculinity in Opera: Gender, History, and New Musicology, ed. Philip Purvis (New York, 2013), the section 'The Tenor Rises', 55-8; John Potter, Tenor: History of a Voice (New Haven, 2009), 44-57, and John Rosselli, 'Grand Opera: NineteenthCentury Revolution and Twentieth-Century Tradition', in The Cambridge Companion to Singing, ed. John Potter (Cambridge, 2000), 96-108.

10 Stendhal dismissed aria substitution as little more than remedy for technical deficiency, a tool for 'exceedingly mediocre singers' to traverse the difficulty of the original composition. Stendhal, The Life of Rossini (Oxford, 2008), 360: 'A second-rate singer [travels] about the countryside completely equipped with a special set of arias, usually referred to as arie di baule or baggage-arias, which are carried around permanently, as it were, like a change of underwear ... A composer may write any music he cares, and insist with legitimate authority upon his performing it, but you may be certain that, by hook or by crook, the singer will find some way of dragging in his baggage-arias.' 
prima donnas such as Giuditta Pasta, Carolina Ungher and Maria Malibran. For these performers, decisions about substitutions entailed careful consideration about musical style and plot consistency. ${ }^{11}$

Departing from Poriss's focus on prima donnas, I focus on male performers, arguing that tenors such as Tacchinardi had many reasons to employ substitute arias, beyond selecting music that flattered their vocal abilities. The recent availability of digitised collections of libretti makes it possible to track substitution practices in more detail than ever, allowing us to compare the content and style of substitute arias across a large number of singers and works. ${ }^{12}$ My comparative study of libretti shows that singers performing male characters sometimes used aria substitutions to enrich and nuance the narrative content of their roles, replacing dramatically static arias with numbers that offered more dynamic situations. In a performance climate centred on the romantic pairing of soprano and musico - that is, a double female lead - male singers carved out a place for themselves by treating aria substitution as a means of plot substitution. As we shall see, Tacchinardi's often drastic choices in substitution were repeated by numerous singers across the 1820 s, creating a stable practice that helped to institute new conventions for masculine-heroic representation. Understood in this way, aria substitution becomes the means in which male singers shift from appearance to doing, and from scripted performance to the semblance of action. In a twist on David Halperin's theory on the gender trouble of masculine performativity in 'Men act, women appear', the male performers I discuss employ aria substitution to reshape roles that position them as appearing rather than acting - a countermeasure to the predetermined script of their action, in which the violence they face, no matter how heroic, is simulated. ${ }^{13}$

While the careers and reception histories of prominent prima donnas and musicos have received considerable attention from scholars of opera studies, the 'rise of the tenor' has almost been taken for granted, its emergent masculinity rushing to fill an obvious void. The early phases of the heroic tenor, before the advent of Adolphe Nourrit and Gilbert Duprez, have been accounted for only by vague gestures towards changes in public taste and the hardening of gender roles in late eighteenth-century Europe. The paucity of historical detail has allowed this particular brand of masculinity - heralded by the technical feat of singing above the staff di petto - to seem a spontaneous and natural emergence, positioning Duprez as a self-made, liberal individual with no tangible predecessors. With a nod to Foucault, Richard Taruskin attributes the decline of the musico to bourgeois domesticity and Victorian morality, while Freya Jarman cites Thomas Laqueur's two-sex theory to argue that audiences across the eighteenth century increasingly understood the boundaries between male

11 Hilary Poriss, Changing the Score (Oxford and New York, 2009), particularly the chapter 'Selecting a "Perfect" Entrance', 37-65.

12 My main resource is the University of Bologna's Corago database: corago.unibo.it. While these online collections are not yet precisely word-searchable, the ease of access to resources from such a large geographical and historical breadth has enabled the study of libretti in a range and scope previously unfeasible through in-person archive access.

13 David Halperin, How to Be Gay (Cambridge, MA, 2012), 242-6, at 243. 
and female to be a fundamental binary difference, rather than a gradation of one essential sex. ${ }^{14}$ Naomi Andre reads this equation of masculinity with procreation into a vignette from Meyerbeer's Il crociato in Egitto, in which the castrato-hero hands over his sword to his successor, the tenor Adriano, in what Andre interprets as an allegorical changing of the guard. ${ }^{15}$ Abbate and Parker similarly resort to allegory to narrate this transition, couching it as a passage from the 'crinoline' and 'corsetry' of florid writing for the male voice to an era that favoured 'the vocal equivalent of stovepipe hats and dark suits'. ${ }^{16}$

A decade ago, Karen Henson wondered in the pages of this journal whether opera studies had reinscribed the very scenario 'it wanted to critique, women staged and scrutinised and men invisible, unhistoricised, unquestioned'. ${ }^{17} \mathrm{My}$ focus on the male singer stresses that the tenor's heroic masculinity is not the natural outcome of the musico's decline; adapting a formulation of Judith Butler's, I want instead to consider that masculinity in opera was an aesthetic identity constructed through hard-won iteration, 'an identity tenuously constituted in time - an identity instituted through a stylized repetition of acts. ${ }^{18}$ By examining substitutions by male singers in Giovanni Pacini's La Sacerdotessa d'Irminsul and Gioachino Rossini's La donna del lago, I reconstruct the substitution practices by which tenors inserted new arias that intensified the active and confrontational dimensions into roles that were otherwise characterised by nobility and restraint. I then turn to Vincenzo Bellini's Norma to examine the only site in which substitution regularly occurred in the opera: the Act II aria for the bass Oroveso. These case studies offer concrete evidence of specific singers who, long before Duprez's famous high Cs, repeatedly altered the operatic text as a means of reinventing the masculine-heroic character. Aria substitution, in this sense, displaces the tired, biocentric framework of vocal prowess and predetermined physiology to allow for more historically sensitive discourses about textual authority and narrative control. Such practices of substitution were the very site of masculine self-invention for the early nineteenth-century male singer.

14 Richard Taruskin, The Oxford History of Western Music, vol. 3 (Oxford, 2005) 35-6. Jarman, 'Pitch Fever', 51-66. Rosselli provided a succinct sketch: 'sex goes a long way to explaining the rise of the tenor ... first he took over from the female contralto the role of lover; then he became a tenore di forza, uttering in his chest voice sentiments of adoration or defiance'. Singers of Italian Opera, 176-7.

15 'The conflict between the two leading male characters, Adriano and Armando, resonates deeply with the tension of changing times ... The nineteenth-century Romantic bel canto vocal style is dramatically symbolised through the sword. With the blatant visual imagery of the potency of the sword, the tenor, more so than the castrato or female travesti singer, emerges as the one most capable for carrying this legacy forward.' Andre, Voicing Gender, 72.

16 Abbate and Parker, A History of Opera, 220.

17 Karen Henson, 'Introduction: Divo Worship', Cambridge Opera Journal 19 (2007), 6. Henson's work on the Verdian dramatic baritone interrogates operatic masculinity in the second half of the nineteenth century. See Henson's Opera Acts (New York, 2014), and 'Verdi, Victor Maurel and Fin-de-siècle Operatic Performance', Cambridge Opera Journal 19 (2007), 59-84.

18 Judith Butler, 'Performative Acts and Gender Constitution', in Performing Feminisms: Feminist Critical Theory and Theatre, ed. Sue-Ellen Case (Baltimore, 1990), 270. Emphasis original. 


\section{Bulking up the tenor in Pacini's La Sacerdotessa d'Irminsul}

While Tacchinardi himself often deployed substitutions throughout his career, he did not hesitate to chastise singers who practised substitution without discretion. Accusations of hypocrisy aside, the terms of his complaint suggest that Tacchinardi did not object to substitutions in principle; nor did he worry much about their effect on an opera's unity or coherence in the terms that we might call a 'work concept'. His concern was more specific, and focused on the consistency of genre:

The contradictions and inconsistencies produced by pastiches, which are commonly made by introducing (so-called) trunk arias, are uncountable. These are inserted wherever caprice dictates; both buffo pieces within serious operas and serious pieces within comic operas reduce the music drama to a parody. ${ }^{19}$

In the same breath, Tacchinardi laments lapses in scenery and costuming: Greek helmets on the heads of Egyptians, Turkish accessories on Scottish bards, Gothic architecture in Semiramide, seventeenth-century costumes in Il barbiere di Siviglia. What is at stake is opera's ability to enthral by sustaining a consistent tone and setting.

It is startling, then, that in his many performances of Pacini's La Sacerdotessa d'Irminsul during the 1820s, Tacchinardi introduced a substitute aria whose narrative content differed drastically from Pacini's original. Written in 1820 as a vehicle for the star castrato Velluti as the hero and love interest Ruggiero, La Sacerdotessa d'Irminsul is built around a typical bel canto love triangle. Romilda (soprano), the priestess of Irminsul, loves Ruggiero (musico), the leader of the enemy Norman army, but for political reasons she is pressured to marry the tenor, Clodomiro, son of the slain Saxon king and protector of the druids. After much confusion and intrigue, the opera ends with the tenor yielding the soprano's hand to the musico, as their marriage will unite the warring Normans and Saxons. Legitimising his new position as the merciful ruler, Clodomiro steps beyond personal motives to enact benevolent authority, true to the eighteenth-century opera seria lineage of his character type.

In his first performances of the role in 1821, Tacchinardi performed Pacini's original entrance aria for Clodomiro, 'Vedo alfin le patrie mura'. Drawing on the conventional situation of a young noble respectfully addressing his honoured, deceased father, the static dramatic pace of this aria positions the tenor as admirable and centrally involved in the political power of familial succession, but not, perhaps, as a locus of passion or romantic energy in the plot.

Clodomiro: Vedo alfin le patrie mura,

L'are antiche alfin saluto:

(S'avvicina alla tomba di Vitikindo)

19 'I controsensi, e le sconnessioni prodotti da pasticci che si fanno comunemente per introdurre i (così detti) pezzi di Baule, sono innumerevoli. Situati questi dove detta il capriccio, e buffi, nell'opera seria, e serj nell'opera buffa, riducono le Drammatiche rappresentazioni in Musica, a sceniche parodie.' Tacchinardi, Dell'opera in musica sul teatro italiano, 56. As translated in Poriss, Changing the Score, 29. 

Io t'adoro o cener muto
Dell'estinto genitor.
Un istante in questo giorno
Ti avvicina; al mio ritorno
Della nostra, e tua sventura
Mi vedrai vendicator.
Coro: $\quad$ Ei ti vede - e il degno erede
Scorge in te - del suo valor. ${ }^{20}$

[At last I see my native walls / ancient altars, at last I salute you (Clodomiro approaches his father's tomb) I adore you, oh silent ashes / of my extinguished father. / That moment approaches / when I return / you will see me vanquish / our, and your, misfortune. / Chorus: He sees you as the rightful heir / of his valour.]

In subsequent performances, however, Tacchinardi replaced the mild and antiquated style of 'Vedo alfin' with an entrance aria from a different Pacini opera, Cesare in Egitto, which the composer had written for the tenor Domenico Donzelli just a few months earlier. ${ }^{21}$ The two arias project very different first impressions of Clodomiro as a character. In the aria from Cesare in Egitto, 'Ma dov'è? Perché sfugge i miei sguardi', the tenor as lover is front and centre, the filial duty and political responsibility that dominated Pacini's original entrance aria for Clodomiro set aside. Even if his dramatic outcome remains the same at the end of the opera, this Clodomiro's point of origin has been significantly altered.

$\begin{array}{ll}\text { Clodomiro: } & \text { Ma dov'è? Perché sfugge i miei sguardi, } \\ & \text { Io Romilda non vedo, non trovo, } \\ & \text { E una smania nell'anima provo } \\ & \text { Che si sente, e spiegar non si sa. } \\ \text { Coro: } & \text { (Mira! Guarda! Ricerca non trova } \\ & \text { Con quei sguardi che dire vorrà?) } \\ \text { Clodomiro: } & \text { La vedrò quest'amabil Sirena } \\ & \text { Che il suo sguardo i più forti incatena } \\ & \text { Pascerò ne' begl'occhi il mio core } \\ & \text { Vagheggiando sì vaga beltà. }\end{array}$

(Clodomiro: But where is she? Why does she avoid my glance? / I do not see Romilda, I cannot find her / and I feel a frenzy in my soul / that I feel but cannot explain. / (Chorus: Look! Look! He searches and does not find; / what do those glances say?) / Clodomiro: I will find my beloved siren / Whose glances will enchain me further; / my heart will be nourished by those beautiful eyes, / rejoicing in such beauty.)

20 Giovanni Pacini, La Sacerdotessa d'Irminsul (Trieste, 1820).

21 Tacchinardi performed 'Vedo alfin' in his first performances of La Sacerdotessa in Lucca 1821. All subsequent performances in Ravenna 1822, Ferrara 1822, Senigallia 1822, and Florence 1823 had 'Ma dov'è?' as the cavatina.

22 Giovanni Pacini, La Sacerdotessa d'Irminsul (Ravenna, 1822). Other libretti containing the aria variably print the opening line as 'fugge i miei', 'sfugge a' miei' or 'fugge a' miei'. 
Both the original and the substituted cavatinas rely on the basic narrative mechanics of looking. While 'Vedo alfin' focuses on the patriotic sentiments invoked by the immediate sight of sacred structures, 'Ma dov'è?' finds its affective charge in the imagined sight of the beloved woman. In both arias, a chorus of onlookers names and affirms these acts of seeing. In this substitution, Tacchinardi reorients the ocularcentric framework operative in both arias, in which to see, or to solicit sight, is to express and confirm character motivations and desires.

The opera from which 'Ma dov'è?' is drawn, Cesare in Egitto, is best known today for a single, violent episode of operatic rivalry. During the opera's premiere performances in December 1821, the title role of Cesare had been sung with great success by Domenico Donzelli, driving the tenor Americo Sbigoli, sharing the stage in the minor role of Tolomeo, to overexert himself in competition with the forceful vocality of the star tenor. As Pacini tells the story in his memoirs:

The quintet of the second act was the cause (to my great sorrow) of the death of the tenor Sbigoli. In singing a phrase similar to that first sung by Donzelli, and wanting to obtain the same applause that Donzelli had aroused, Sbigoli forced his voice in such a way as to produce a jet of blood, so that a short time thereafter he left behind a wife and son in desolation. ${ }^{23}$

Donzelli, a noted 'baritenor' with a reputation for singing 'too high in chest voice and therefore becoming too loud', has been traditionally cast by opera historians as an early example of the tenore di forza, a heavier and darker voice that by the 1830s would become the archetype of heroic action. ${ }^{24}$ The unfortunate Sbigoli, in contrast, had specialised in Rossinian tenore di grazia roles such as Lindoro (L'Italiana in Algeri), Almaviva (Il barbiere di Siviglia), and Giannetto (La gazza ladra), a type whose decorated aesthetic would eventually cede to the darker, more declamatory style. In histories of the nineteenth-century singer, Sbigoli's fatal performance has been widely instrumentalised as support for a hierarchy of masculine archetypes among tenor performers. ${ }^{25}$ With the gendered rhetoric of Donzelli's potency (and Sbigoli’s implied

23 ' 1$] 1$ quintetto dell'atto secondo, che fu causa (con mio gran dolore il dico) della morte del summentovato tenore Sbigoli: imperocché, avendo egli una frase simile a quella che prima era proposta dal Donzelli, per volere ottenere gli stessi applausi dal pubblico che il Donzelli riscuoteva, sforzava siffattamente la voce, che gli produsse un getto di sangue, per la qual cosa dopo poco tempo lasciò una moglie ed un figlio in mezzo alla desolazione.' Giovanni Pacini, Le mie memorie artistiche (Bologna, 1978), 28.

24 Potter, ed., The Cambridge Companion to Singing, 98; for a more recent take on Donzelli see also Davies, 'In Search of Voice: Nourrit's Voix Mixte, Donzelli's Bari-Tenor', in Romantic Anatomies, $123-51$.

25 Sbigoli's manner of death as reported by Pacini is cited in Giorgio Appolonia, 'Diagnosi, terapia e riabilitazione nelle patologie vocali del cantante dell'ottocento', in La voce del cantante, vol. 1, ed. Franco Fussi (Turin, 2000), 244; William Ashbrook, Donizetti and His Operas (Cambridge, 1982), 22-3; Guglielmo Barblan, Donizetti: vita e opere di un musicista romantico (Bergamo, 1983), 66-7; Annalisa Bini and Jeremy Commons, Le prime rappresentazioni delle opere di Donizetti nella stampa coeva (Milan and Rome, 1997), 69-70; Alberto Cametti, Un poeta romantico romano (Milan, 1898), 116-18; Rodolfo Celletti, Voce di tenore (Milan, 1989), 93; Maurizio Modugno, 'Domenico Donzelli e il suo tempo', Nuovo rivista musicale italiana 18 (1984), 207; Gino Moldani, I teatri di Roma negli ultimi tre secoli (Naples, 1928), 146; Henry Pleasants, The Great Singers (London, 1967), 160; John Potter, 
impotence), scholars who bring up this Cesare in Egitto incident establish a sensational crux to the 'rise of the tenor' narrative: light-voiced Sbigoli's failure to match the heroic chest-tones of his rival allegorises the literal death of a dated, over-stylised masculinity unable to imitate its virile and forceful successor.

In light of this primal scene of tenor masculinity, it is tempting to understand Tacchinardi's choice of a substitute aria from Cesare in Egitto, mere months after Sbigoli's death, as a bid to capitalise on the mythic masculinity of Donzelli's chest voice (a lethal $\mathrm{g}^{1}$ from the chest, precursor to Duprez's do di petto). After all, Tacchinardi's chest voice extended to the same note: his falsetto began after $\mathrm{g}^{1}$ and extended to $c^{2}$ and François-Joseph Fétis recorded that Tacchinardi had no difficulty manoeuvring between his chest and head voices (although some contemporary critics noted otherwise). ${ }^{26}$ The connection may be more wishful than actual, however, as indeed may be the entire narrative of Sbigoli's death. While the press, writing immediately after the Cesare in Egitto incident, lamented Sbigoli's untimely death and the misfortune of his surviving wife and children, his demise was never described in the sensational terms adopted by Pacini, whose account was published four decades later in 1865; one journalist at the time attributed the tenor's death to a 'nervous fever'. ${ }^{27}$ Pacini likely amplified the incident retrospectively, revealing the links between tenor vocality and masculinity that were mainstream by 1865 , but latent or even non-existent in the 1820s.

Pacini's revisionism casts into doubt the precise relationship between vocal timbre and masculine performance during Tacchinardi's career and the privileged position of the chest voice in histories of opera. Such language as a critic's preference 'to hear a man's voice from a man's chest' and the distaste for 'those little fluted falsetto notes that make one doubt the virility of he who produced them' did eventually enter operatic discourse, but from the French side, and after 1837, in tandem with Duprez's much-studied feats. ${ }^{28}$ Berlioz, for instance, described the singer's high notes, in chest voice, as 'a resonant fullness, an expression of heart-rending grief, and a beauty of tone that so far nothing had led one to expect. A petrified silence reigns in the house, people hold their breath, amazement and admiration are blended in a mood

Tenor: History of a Voice (New Haven, 2009), 50; Mario Rinaldi, Due secoli di musica al Teatro Argentina (Florence, 1978), 582-3; and Herbert Weinstock, Donizetti and the World of Opera in Italy, Paris, and Vienna (New York, 1963), 26-7.

26 Allgemeine Musikalische Zeitung (22 January 1817), 61, and 5 February 1817, 106. François-Joseph Fétis, Biographie universelle des musiciens et bibliographie générale de la musique, VIII (Brussels, 1972), 172-3.

27 The Gazette di Firenze (28 February 1822), 4, mentions no cause of death. Morgenblatt für gebildete Stände (2 March 1822), 212, cites a case of 'Nervenfieber'.

28 La Presse 270 (10 April 1837), as quoted and translated in Davies, Romantic Anatomies, 124. On Duprez and the do di petto, see Gregory Bloch, 'The Pathological Voice of Gilbert-Louis Duprez', Cambridge Opera Journal 19 (2007), 11-31; and Marco Beghelli, 'Il "do di petto": dissacrazione di un mito', Il saggiatore musicale 3 (1996), 105-49. See also Mary Ann Smart's 'Roles, Reputations, Shadows: Singers at the Opéra, 1828-1849', in The Cambridge Companion to Grand Opera, ed. David Charlton (Cambridge, 2003), 108-28. 
akin to fear. ${ }^{29}$ But language that wedded a darkened timbre to heightened emotion, amazement akin to fear, or particular gendered archetypes was unknown in the Italian press in the $1810 \mathrm{~s}$ and 1820 s, where the tenor's chest voice was mentioned only in comment to his ability to manoeuvre the register break into falsetto. Italian critics lauded Tacchinardi's singing with consistent praise throughout his career, calling him an accomplished singer, a 'first rate tenor' with a round, pleasant tone, praising his flexible and effortless fioritura, and the clarity of his pronunciation ('never was every syllable pronounced so intelligibly'). ${ }^{30}$ It was simply not in parlance to link any of these vocal descriptions to the singer's ability to perform a role's masculinity.

Studies of the tenor, then, cite Pacini's account of Sbigoli's misfortune to read the connection between timbre and masculinity back from later decades, just as Duprez himself, reminiscing in 1880, would characterise his 1837 high Cs from the chest as 'manly accents and sublime cries. ${ }^{31}$ Henry Pleasants comes close to admitting the non-historicity of such developmental narratives: '[Donzelli's] contemporaries cannot be expected to have foreseen the royal line running from Nourrit through Duprez, Mario, Tamberlik, Tichatschek, Campanini, de Reszke, and Tamagno to Caruso.,32 The chest voice may have indeed 'risen' and darkened the timbre of the tenor voice during the careers of Donzelli, Nozzari, and Tacchinardi, but the gendered meanings that are now attached to that timbre are certainly later accretions that cannot be assumed to apply to their technical progenitors. Contemporary reviews here discuss the tenor's ability to manoeuvre the chest voice as an absolute technical feat with its own aesthetic boundaries, rather than a complex locus of gender constitution.

In contrast to the non-specific superlatives used to describe Tacchinardi's voice, critics paid much attention to descriptions of Tacchinardi's body. Reviews across Europe reported how audiences initially ridiculed and gawked at Tacchinardi's ungainly physical appearance, only to change their minds upon hearing him sing.

29 Berlioz, trans. Jacques Barzun, Evenings with the Orchestra (New York, 1956), 65-6. This description was not published until 1852. Even the kind of evidence routinely given in scholarship on Donzelli, such as Henry Chorley's detailed description of the tenor's voice, was written as late as 1862. See Potter, Tenor: History of a Voice, 50, and Henry Chorley, Thirty Years' Musical Recollections (London, 1972), 4. See also Pleasants, The Great Singers, 159-61. Rosselli's description of Donzelli's voice has no citations at all. J.Q. Davies's French sources on Donzelli, written after the late 1830s, agree with my hunch of post-factum, career-end mythologising. Davies describes Donzelli's voice as a 'fractured apparatus', a 'hole' between chest and head tones, while Rosselli praises the tenor for his 'imperceptible shift ... between chest and head registers'. Davies, Romantic Anatomies, 1367; Rosselli, 'Grand Opera', 98-99.

30 Tacchinardi was 'the finest of singers', of 'extraordinary merit in singing', so admirable for his 'excellence of arts' that 'every other tenor ought to recoil with shame', 'other tenors should turn pale to sing after him', his performances inebriated audiences such that they 'forget they have ever heard any other singer in the role'. Reviews of Tacchinardi glossed here include the Allgemeine Musikalische Zeitung 23 December 1807, 203; 8 March 1809, 357; 6 February 1811, 110-11; 22 January 1817, 61; 5 February 1817, 107-8; 8 December 1821, 778; 17 May 1823, 317; Il Galiani, 10 August 1824, 109; Gazzetta di Firenze, 28 February 1815, 4; Gazzetta privilegiata di Venezia, 13 March 1816, 3-4; 8 April 1816, 4; I Teatri, 20 August 1827, 315; 27 January 1828, 697; 28 January 1828, 269; and Teatri arti e letteratura, 1 December 1827, 126; 13 May 1825, 52-3.

32 Pleasants, The Great Singers, 159. 
'I am here to be heard, not to be seen', Tacchinardi allegedly exclaimed while on stage, in response to the audience's reaction to his physique. ${ }^{33}$ Specific criticism about Tacchinardi's physique far outpaced description of his voice: his figure was 'small and not well-formed', 'visually unsatisfying' and 'disadvantageous for the theatre'. Tacchinardi's body (and not his voice) was criticised as unsuitable for Don Giovanni, a far-from-heroic character who was nonetheless hypermasculine. ${ }^{34}$ Fétis noted the hushed whispers about his hunchback (reports of its severity varied through time and geography), and Jarro recorded a thorough description of the singer's physique: straight, unhunched shoulders, but squat of body, an expressive face (which, unlike Rubini's, was not etched with smallpox), a wide and stocky torso, robust legs, but protrusive knees. ${ }^{35}$ It is no wonder that Tacchinardi focused so much of his polemic on the musico's stage decorum and bodily comportment, as his own physique has perpetually been diagnosed as failing expectations of masculine-heroic performance. In his exclamation - that he was not on stage to be seen - we see the self-consciousness of a performer who is hyperaware of the workings of the gaze in the theatre, and whose signature substitute arias (about which more below) also foreground the male gaze. These substitutions were later widely emulated, and not only by tenors: soprano- and contralto-musicos were also inspired to take up Tacchinardi's sight-staging arias. Talk of chest-register masculinity becomes moot when the same tenor arias can be taken up by female voices in masculine-heroic roles.

\section{The Uberto Problem and the Tacchinardi Fix}

We have seen Tacchinardi's substitution practices in the role of Clodomiro. What, then, of other operas with far more extensive circulation across the early nineteenth century than La Sacerdotessa d'Irminsu? In addition to Sacerdotessa, Tacchinardi's most frequently performed roles across the 1820s were Uberto in Rossini's La donna del lago and the title role in Otello. In both La Sacerdotessa and La donna del lago, Tacchinardi would try out the role as written at its first run of performances, then substitute an aria of his own choosing in subsequent productions. (see Table 1 for an overview of Tacchinardi's substitutions discussed in this article.) As the table shows, Tacchinardi's substitution strategy maintained a consistency throughout his career in these roles: the Pacini arias 'Ma dov'è?' and 'Essa il mio cor rapi' were not merely interchangeable 'arie di baule' to be switched in and out of roles, but became fixed components of his conception of Clodomiro and Uberto. Tacchinardi's adjustments did not go unnoticed; they must have been well received, since they were copied by

33 'Sono venuto qui per farmi ascoltare, non per farmi vedere'. The anecdote, according to Fétis, occurred during a performance of Zingarelli's Distruzione di Gerusalemme in 1811. Biographie universelle, 172.

34 AMZ (15 January 1812), 42.

35 Jarro (Giulio Piccini), Memorie di un impresario fiorentino (Florence, 1892), 122-7. 
Table 1: Nicola Tacchinardi's aria substitutions

\begin{tabular}{lll} 
Host opera & \multicolumn{1}{c}{ Tacchinardi's substitute aria } & Tacchinardi’s performances \\
\hline La Sacerdotessa d'Irminsul (Pacini) & 'Ma dov'è? Perché sfugge i miei sguardi' & Lucca 1821 (as written) $^{\mathrm{a}}$ \\
& from Pacini’s Cesare in Egitto & Ferrara 1822 \\
& & Senigallia 1822 \\
La donna del lago (Rossini) & & Florence 1823 \\
& & Vicenza 1826 \\
& 'Essa il mio cor rapì & Milan 1821 (as written) \\
& from Pacini’s Temistocle & Trieste 1822 \\
& & Florence 1824 \\
& & Florence 1832
\end{tabular}

${ }^{a}$ All libretti consulted were accessed in person at Hargrove Library, the University of California, Berkeley, or online through the Corago libretto collections database operated by the Università di Bologna at corago.unibo.it.

many tenors of the following generation. ${ }^{36}$ While La Sacerdotessa did not enjoy a robust revival after Tacchinardi's performances, La donna del lago was popular throughout the 1820s, along with the practice of substituting 'Essa il mio cor rapi'. The tenors who followed Tacchinardi also expanded the reach of these substitute arias, inserting the same two arias by Pacini into different operas by various other composers (see Table 2). Even in roles that Tacchinardi himself had sung without employing aria substitution, younger tenors who took up the same role later would sometimes insert Tacchinardi's signature substitute arias. ${ }^{37}$

Tacchinardi did not invariably practice cavatina substitution in all his roles, however. In contrast to his approach to the roles of Clodomiro and Uberto, he adhered faithfully to the original text when performing in Rossini's Otello. In a performance climate where other Otellos, most Desdemonas and even Desdemona's handmaid Emilia tirelessly rotated substitute arias into the opera, Tacchinardi never replaced any of Rossini's music in any of his seven productions of Otello, despite sharing the stage with five other tenors in the opera (two major and three minor). The explanation may be simple: in Otello, Tacchinardi's character was the star and the title character, and the opera already revolved around his interests.

As this stage masculinity relied on situation and appearance more than gendered vocality, Tacchinardi's substitutions were also adopted by musicos: the soprano

36 It is difficult to rely on the Italian journalistic archive for evidence of the reception of substitute arias, because critical discourse in this vein simply was not well-developed in the 1810s and 1820s. Even when substitutions are noted in reviews, they are discussed in a matter-of-fact way, without judgement or with little explanation as to why the substitution pleased or displeased. See, for example, I Teatri (27 January 1828), 697, and Allgemeine Musikalische Zeitung (24 April 1822), 277. Instead, I would like to reformulate the locus of proof here away from critical journalism, and into performance practice itself. That Tacchinardi received the composer's written part, then

reconceived and inflected it in a new way, is a form of reception upon the composer's work. In the same way, that a multitude of musicos and young tenors after him chose to emulate such practices are themselves acts of positive reception on Tacchinardi's alteration.

Tacchinardi performed Mayr's La rosa bianca e la rosa rossa and Mercadante's Didone Abbandonata, for instance, without substitution. Pietro Gentili and Bernardo Winter still performed these operas with the mentioned Pacini arias. 
Table 2: Aria substitution by subsequent singers after Tacchinardi

\begin{tabular}{|c|c|c|c|}
\hline Opera & Performer & Performance & Aria \\
\hline \multirow[t]{8}{*}{ La donna del lago (Rossini) } & Nicola Tacchinardi & Trieste 1822 & 'Essa il mio cor rapi' \\
\hline & & Florence 1824 & 'Essa il mio cor rapi' \\
\hline & & Florence 1832 & 'Essa il mio cor rapi' \\
\hline & Raffaello Martini & Florence 1825 & 'Essa il mio cor rapi' \\
\hline & Giuseppe Fosconi & Reggio 1825 & 'Essa il mio cor rapi' \\
\hline & Pietro Gentili & Siena 1827 & 'Essa il mio cor rapi' \\
\hline & Rosmunda Pisaroni (musico) & London 1829 & 'Essa il mio cor rapi' \\
\hline & Giuseppe Pennetti & Foligno 1830 & 'Essa il mio cor rapi' \\
\hline Fedra (Orlandi) & Rosa Morandi (musico) & Florence 1823 & 'Ma dov'è?' \\
\hline Arminta ed Argia (Mercadante) & Rosa Morandi (musico) & Reggio 1823 & 'Ma dov'è?' \\
\hline La sposa fedele (Pacini) & Giuseppe Vaschetti & Livorno 1826 & 'Essa il mio cor rapi' \\
\hline La rosa bianca e la rosa rossa (Mayr) & Bernardo Winter & Cremona 1824 & 'Essa il mio cor rapi' \\
\hline Didone abbandonata (Mercadante) & Pietro Gentili & Venice 1827 & 'Ma dov'è?' \\
\hline Adele ed Emerico (Mercadante) & Lodovico Sirletti & Lodi 1828 & 'Ma dov'è?' \\
\hline Semiramide (Rossini) & Pietro Gentili & Genoa 1829 & 'Ma dov'è?' \\
\hline
\end{tabular}

Rosa Morandi, who shared the stage with Tacchinardi in performances of La Sacerdotessa as his musico rival Ruggiero, chose to perform 'Ma dov'è?' as the substitute cavatina in her own musico roles such as Ippolito (Orlandi's Fedra) and Aminta (Mercadante's Aminta ed Argira). ${ }^{38}$ Rosmunda Pisaroni would follow suit, inserting 'Essa il mio cor rapi' into her performances as Malcom in La donna del lago. ${ }^{39}$ Such emulations by soprano and contralto performers in male roles attest to the effectiveness of Tacchinardi's substitutions, regardless of vocal register. Singers who emulated Tacchinardi's substitutions stood to gain from association with his fame and virtuosity; but, perhaps just as important, they would also project a consistent brand of stage masculinity. Through singing the same substitute arias, tenors and musicos after Tacchinardi collectively invoked a set of traits newly perceived on the stage as masculine, reinforced and legitimised across the 1820s - as in Butler's formulation - through constant repetition. ${ }^{40}$ In this sense, a substitute aria such as 'Ma dov'è?' did not serve as a cushion for technical mediocrity, as critics such as Stendhal had accused, but rather contributed to an emergent masculine aesthetic that was constituted and stabilised through imitation and repetition.

Rossini's La donna del lago presents a unique case through which to examine the tenor's evolving persona as a heroic type, with its three contrasting male characters each vying for the prima donna's affection. In this romantic fantasy of the highlands, urban Scotland, ruled by King James V, is at war with its mountain clans. Elena, the

38 Ferdinando Orlandi, Fedra (Florence, 1823); Saverio Mercadante, Aminta ed Argira (Reggio, 1823).

39 For an account of Pisaroni's debut at the King's Theatre in 1829, see John Edmund Cox, Musical Recollections of the Last Half-Century, vol. 1 (London, 1872), 167-8.

40 'Repetition is at once a reenactment and reexperiencing of a set of meanings already socially established; it is the mundane and ritualized form of their legitimation.' Butler, 'Performative Acts and Gender Constitution', 277. 
lady of the lake, is in love with the rebel chieftain Malcom, a musico role written for the aforementioned contralto Rosmunda Pisaroni. His fierce rival is Rodrigo Dhu, written for Andrea Nozzari, a 'baritenor' type for whom Rossini also wrote Otello. The role of James $\mathrm{V}$ (disguised for much of the opera as the commoner Uberto) was conceived for and first performed by the tenor Giovanni David.

Like Clodomiro in Pacini's La Sacerdotessa, Uberto is an aristocratic political leader, to whom the heroine shows affection not out of romantic love, but out of duty and hospitality. True to his opera seria type, Uberto bestows mercy on the defeated highlanders at the end of the opera, and sacrifices his own affection for Elena by endorsing her marriage to Malcom. Exercising the authority of his throne, Uberto stands in contrast to Rodrigo and Malcom, violent tribal leaders involved in military action and political confrontation. Heather Hadlock has shown how Uberto, modelled on the vocal and dramatic profile of the singer who created the role, relied on tropes of a tenuous and dated masculinity:

The light voice and gallant persona of Giovanni David served the opera's idealized image of the aristocratic male as purified of self-serving impulses, and empowered by that purification to claim benevolent authority, bestow personal happiness, and restore political order. In the character of the king, the opera and its source poem depict the aristocratic 'man of feeling' as an essentially comic and feminine force ... [This] magnanimity seems always in danger of collapsing into unmanly weakness, and noble self-sacrifice into weak lack of self-assertion. ${ }^{41}$

As Hadlock further argues, the character's stylised, aristocratic type was most visible in Uberto's cavatina 'O fiamma soave'. The aria features sparse orchestration that makes way for the tenor's florid melismatic passagework above the staff, highlighting his dexterity in navigating intricate vocal embellishment. Its dramatic stasis and measured poetry prevent the tenor from appearing as an active and dynamic hero, instead casting him as a distant observer, sighing for the heroine from afar. While the aria may have been successful within the dramatic and aesthetic horizons of the 1810s, such ornate masculinity caused subsequent tenors much trouble in the ensuing years. By 1824, Stendhal would call it 'the most tedious thing in the world, being overloaded with vulgar little ornaments'. ${ }^{2}$ The 'sentimental heroism' of Uberto, then, due to its ornate, gallant characterisation and seria and semiseria roots, projected precisely the traits that Tacchinardi had sought to refashion in La Sacerdotessa's Clodomiro.

Compared to the relative textual stability of its other two male leads, the role of Uberto faced constant reinvention whenever the opera was revived across the 1820s. As a case in point, the delicate 'O fiamma soave' (Example 1) has proven

41 Hadlock analyses the different registers of performative masculinities in La donna del lago, reading both Walter Scott's source poem and Rossini's opera for their methods of conveying a spectrum of masculinities. Heather Hadlock, 'Different Masculinities', in Retbinking Difference in Music Scholarship (New York, 2015), 170-213, at 202 and 209.

42 As cited and translated in Hadlock, 'Different Masculinities', 204. 

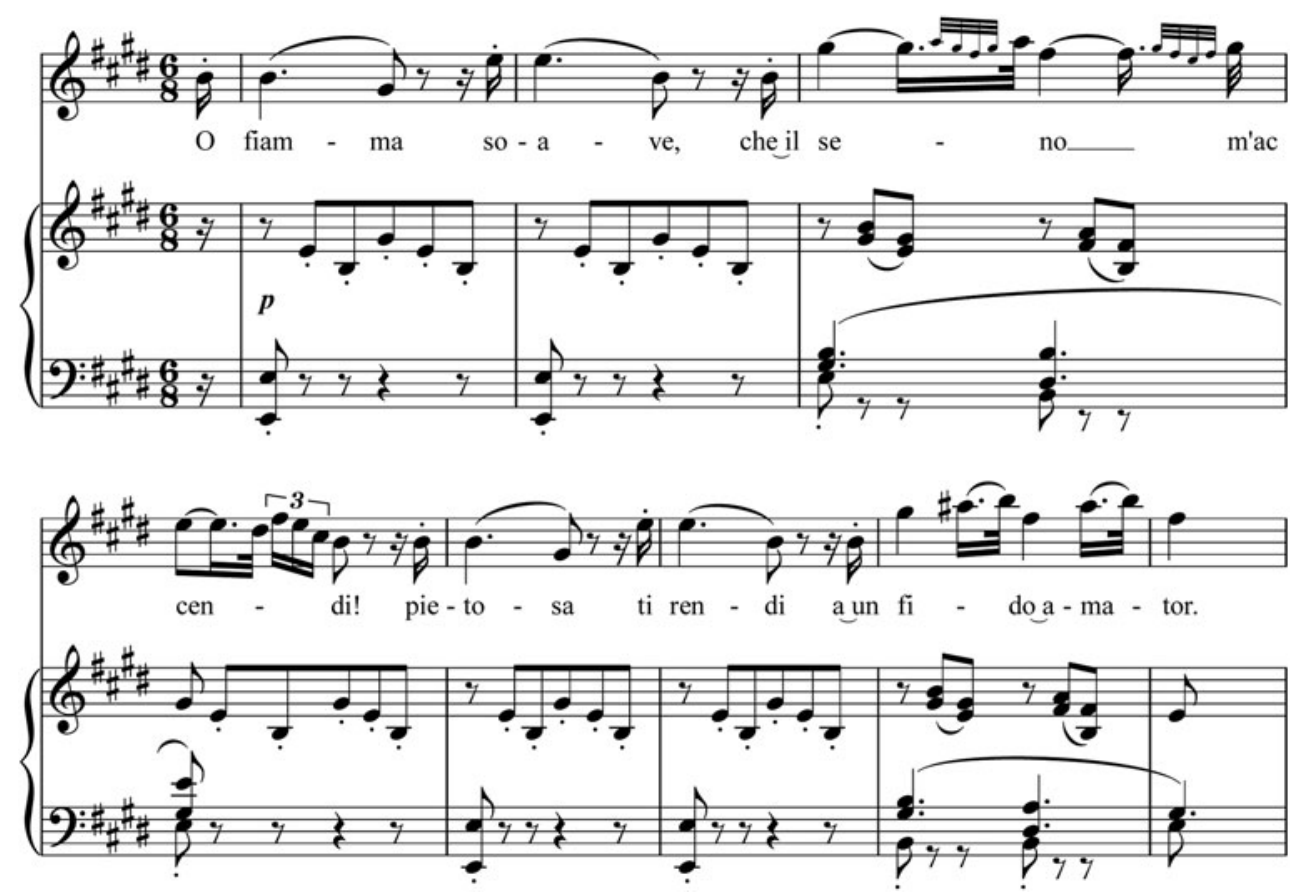

Ex. 1: Gioachino Rossini, 'O fiamma soave', bb. 42-50.

so difficult to execute dramatically that even David himself, starting in 1823, abandoned it for a substitute aria, sometimes omitting the solo opportunity entirely. La donna del lago's lasting popularity through the 1830s meant that tenors performing Uberto, an aesthetic type quickly outdated after its premiere, managed the role through substitutions which altered both his musical style and dramatic situation.

As Table 3 a shows, performing Rossini's aria as written seems to have been an infrequent and short-lived preference. It is surprising just how often ' $\mathrm{O}$ fiamma soave' went unperformed in the opera's first two decades of circulation, frequently supplanted by 'Essa il mio cor rapì'. Tacchinardi's substitution choice had stabilised as part and parcel of the opera itself in its early performance history: performances of La donna del lago that featured the Pacini substitute far outnumbered performances of Rossini's original music. The twenty-six known instances of substitution detailed in Table $3 \mathrm{~b}$ testify not only to the untenability of dramatically static, florid-singing aristocratic masculinity across the 1820 s and 1830 s, but also to the degree and severity of the substitutions. ${ }^{43}$ Tenors in the role of Uberto were looking not only for more vocally suitable music, but also for entirely different registers of narrative action.

43 Florid-singing masculinity did not die out completely with Uberto, and experienced a late surge in the tenor Giovanni Battista Rubini, for whom Bellini wrote the role Elvino in La sonnambula - a 
Table 3a: Substitution history of La donna del lago, Act II opening

Performances of La donna del lago presenting 'O fiamma soave'

1819 Naples (premiere)

1820 Palermo

1821 Milan (Tacchinardi's first Uberto)

1822 Padova

1824 Milan

Table 3b: Substitution history of La donna del lago, Act II opening

Performances of La donna del lago with 'O fiamma soave' omitted or substituted

\begin{tabular}{ll}
\hline 1821 Venice (omitted) & 1827 Siena (Gentili subs 'Essa il mio cor') \\
1822 Bologna (Bertozzi subs 'Giusto ciel che i mali miei' & 1827 Palermo (omitted) \\
from Rossini's Sigismondo) & 1828 Vicenza (David omits solo, subs duet from Pacini's Gli \\
1822 Trieste (Tacchinardi subs 'Essa il mio cor') & arabi nelle Gallie) \\
1822 Verona (omitted) & 1829 Cadiz (Pasini subs 'Un giorno appien beato' from \\
1822 Lucca (omitted) & Rossini’s La pietra del paragone) \\
1823 Rome (David subs 'Matilde, anima mia' from & 1829 London (Pisaroni subs 'Essa il mio cor') \\
Rossini's Matilde di Shabran) & 1830 Bologna (omitted) \\
1823 Barcelona (omitted) & 1830 Rome (omitted) \\
1823 London (omitted) & 1830 Foligno (Pennetti subs 'Essa il mio cor') \\
1824 Paris (subs scene from Rossini's & 1832 Florence (Tacchinardi subs 'Essa il mio cor') \\
Bianca e Falliero, under composer supervision) & 1832 Venice (Alberti subs 'Risplendi o suol beato' from \\
1824 Bergamo (omitted) & Raimondi’s Argia) \\
1824 Florence (Tacchinardi subs 'Essa il mio cor') & 1837 Turin (omitted) \\
1825 Reggio (Fosconi subs 'Essa il mio cor') & 1838 Milan (omitted) \\
1825 Florence (Martini subs 'Essa il mio cor') & 1841 Naples (omitted)
\end{tabular}

Seeking to supplant the dated trope of static praise from afar, performers did not merely alter or omit ' $\mathrm{O}$ fiamma soave': they swapped the following scene with Elena and Rodrigo for completely different scenarios involving different sets of characters. In Paris in 1824, under Rossini's own supervision, a new scene was introduced where Douglas and Rodrigo discover Malcom and Elena locked in sweet embrace, and the four engage in a confrontation quartet borrowed from the composer's Bianca e Falliero. The same situation is repeated with minor adjustments in Turin in 1837 and Milan in 1838. In Venice in 1832, Elena does not show up at all, yet Uberto and Rodrigo argue nevertheless through a duet borrowed from Donizetti's Gabriella di Vergy. In certain productions (Bergamo, 1824, and Vicenza, 1828, by means of different substitutions), Uberto and Malcom sing a duet, with no Rodrigo in the picture. Giovanni David himself in Vicenza in 1828 chose to substitute a tenor-soprano duet that opens

character that, however, could hardly be called heroic; see Emanuele Senici, Landscape and Gender in Italian Opera (New York, 2005), 21-92. 
Act II of Pacini's Gli arabi nelle Gallie, where a misunderstanding between husband and wife (he in Arabian disguise, she believing the Arab had killed her husband) turns into a duet between Uberto and Malcom: the enraged wife's accusations become Malcom's, and the mistaken husband's placation and justification becomes Uberto's. Throughout the 1820s performers of La donna del lago's masculine leads were in search of decisive and dangerous dramatic situations in which to display themselves, with the understanding of the privileged position of doing/action at the double level of performer and character. This wholesale rejection of a specific scene in an opera with such an extensive performance history is striking: the practice highlights the textual instability of the bel canto repertoire, an instability that not only disrupts at the level of the aria, but also can affect collections of scenes and significant portions of plot altogether. Amidst this sea of constant change, Tacchinardi's choice of 'Essa il mio cor rapi' turned out to be the most stable solution.

As we have seen, Tacchinardi abandoned ' $O$ fiamma soave' after attempting it in his first performances as Uberto at La Scala in 1821, preferring to substitute 'Essa il mio cor rapi' from Pacini's Temistocle for all future performances - a practice also adopted by the tenors Raffaello Martini, Giuseppe Fosconi, Pietro Gentili, and Giuseppe Pennetti. By replacing 'O fiamma soave' with the aria by Pacini, Tacchinardi and his emulators jettisoned the dramatic stasis of Rossini's original, in which the tenor praises the absent, adored woman, with a far more active scene of yearning (Example 2):

Ma dove il troverò? Elena cara,

Incantatrice Dea, non ocultarti;

Riedi co' tuoi bei sguardi a questo core,

E da' tregua nel seno al mio dolore. ${ }^{44}$

(But where shall I find her? Dear Elena, / enchantress, Goddess, do not hide yourself / with your beautiful gaze return to this heart / and give respite to the sorrow in my breast.)

Pacini's setting of this excerpt from 'Essa il mio cor rapi' emphasises the tenor's rhetorical longing, 'ma dove', as a pivot between recitative and arioso, and between plot explication and outburst of sentiment. The passage strikingly resembles the ocularcentric demands of Tacchinardi's other signature substitution, 'Ma dov'è? Perché sfugge i miei sguardi'. Both situations cast the tenor as seeking the adored woman, declaiming her name, demanding that she appears before his eyes, and describing what her presence would do to soothe his heart. Indeed, Uberto's new text also bears a strong resemblance to the rebel leader Rodrigo's Act I entrance aria in La donna del lago:

Ma dov'è colei, che accende

Dolce fiamma al mio seno?

De' suoi lumi un sol baleno

Fa quest'anima bear!

44 Gioachino Rossini, La donna del lago (Florence, 1824). 

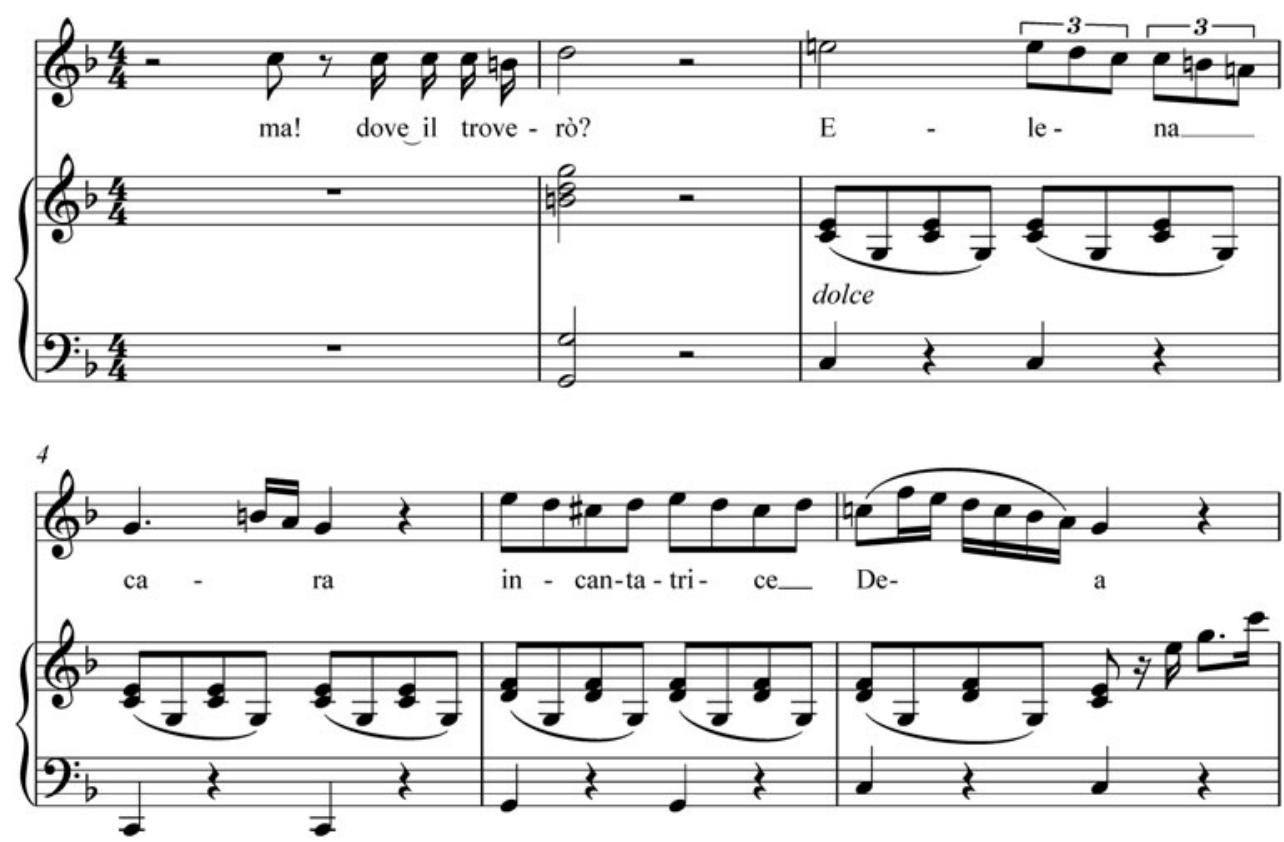

Ex. 2: Giovanni Pacini, 'Essa il mio cor rapi’, bb. 53-58.

(But where is she / who ignites such a sweet flame in my breast? / A single glance from her / fills my being with joy.)

Such demands for the heroine's presence supplanted the dated gallantry of arias that heaped her with stately praises from afar (or in Clodomiro's case, similar praises of his deceased father). This new model of stage masculinity not only discarded florid ornamentation - the excuse for non-action - but was also defined by the repetition of a dramatic motif: repeatedly demanding an object for the gaze. Even Malcom, in his cavatina 'Mura felici', envies the cottage walls because they constantly have Elena within their sight. When Uberto demands to see Elena's body, he aligns his masculinity, through repetition, with the fierceness of Rodrigo, who also demanded Elena's body in his cavatina. As these roles are passed from singer to singer, re-enacted after Tacchinardi by Martini, Fosconi, Gentili, Pisaroni, and Pennetti, repeated performances amplify the echoed proliferation of the male gaze, bouncing around in the contained space of this opera. The three male characters, and the many tenors and musicos who sing them, create and recreate an image and idea of Elena, trapped in a hall of mirrors, where looking and seeing are a measure of masculinity, legitimised through re-enactment. 


\section{Norma's immutable text and the problem of the bass}

While the tenor lead of La donna del lago faced constant revision and reinvention during the 1820s, the popular star vehicle of the next decade, Bellini's Norma, made its way across Europe with virtually no substitutions imposed on the tenor part. ${ }^{45}$ Indeed, in a performance climate where scene substitution continued to be commonplace, Norma's performance history stands out for the stability of its plot and arias (see Table 4a). ${ }^{46}$ The reason for this lack of change may be as straightforward as not fixing what already works: whenever the tenor hero Pollione is on stage, it is to confront danger in some way, and he is the sole love interest caught between two women, with no musico in sight. For restrained opera seria types Clodomiro and Uberto, once a solution for problematic masculine presentation is found, that musical solution becomes textually stabilised. For Otello and Pollione, roles whose heroic masculinity was already decisive, virile and dangerous, substitution did not occur.

Across Norma's first decade of performance, the few substitutions that did occur targeted the Act II aria for the bass Oroveso, Norma's father and leader of the druids (see Table 4b). ${ }^{47}$ I turn from the tenor to the bass here to demonstrate that the performative paradigm of stage masculinity I discuss is not circumscribed by vocal category among tenor-voiced, male-bodied performers, but could come into play in any role that was gendered male in the narrative. That tenors, basses and musicos all used

45 Susan Rutherford has shown that Giuditta Pasta's success as Norma derived partially from the monumentality of her acting, her gestures calculated to be precisely in time with the music. Even Maria Malibran, who famously personalised her performances of I Capuleti e $i$ Montecchi by replacing the entirety of Bellini's final scene with Vaccai's, made her mark on Norma not through substitution, but through a new approach to acting - a freer, less metronomic, less synchronised approach to gesture which critics felt aptly captured the emotional turbulence of the role. Pasta's statuesque priestess becomes Malibran's vivid mother, with Bellini's music intact. Giuditta Pasta's ownership of the role, as Rutherford argues, was so complete that singers who later attempted the role felt bound to demonstrate that they could match her in the same difficult music, on her terms. In this way, we could also understand the lasting effect of Tacchinardi's 'Essa il mio cor rapi' as exerting ownership over the role Uberto, with the multitude of singers attempting to match the star tenor in performance of the same music. Susan Rutherford, 'La cantante delle passioni', Cambridge Opera Journal 19 (2007), 123-6.

46 This is not to say that 1831 is the cutoff point at which anything like the work concept solidified within the Italian repertoire. Donizetti's Lucia di Lammermoor, 1835, for example, was often performed without Lucia's cavatina (the fountain scene, 'Regnava nel silenzio') and even altogether without the now-famous mad scene. See Hilary Poriss, 'A Madwoman's Choice: Aria Substitution in Lucia di Lammermoor', Cambridge Opera Journal 13 (2001), 1-28.

47 The substitutions outside of Oroveso can be easily explained away. The tenor Alberico Curioni switched Pollione's cavatina for a different one in Ancona in 1833. Just a few months later in Bologna, he sang it as written, as if some invisible hand has chastised him for the action. Giving Adalgisa an inserted aria in between Oroveso's 'Ah! Del Tebro' and Norma's 'Ei tornerà' seemed to be a short-lived Florentine specialty, as Anna Del Sere and Carolina Macchi had done. Another production in Livorno 1834 turned Clotilda into Lisippo, changing Norma's handmaid into a manservant. This seems to be a result of provinciality and budgetary reasons rather than artistically motivated, as Lisippo is played by the same singer as the role of the Roman soldier Flavio. The common insertion, 'Di terror, di strage armato', remains the only text in this project whose source opera I cannot identify. This raises the possibility that the cabaletta may be written especially as an insert for performing Oroveso. The text of 'Di terror' repeats the sentiment of Bellini's preceding material. 
Table 4a: Substitution history of Norma

Performances of Norma without aria substitution

\begin{tabular}{ll}
\hline Milan 1831 (Premiere) & Barcelona 1835 \\
Bergamo 1832 & Cremona 1836 \\
Venice 1832 & Reggio 1836 \\
Bologna 1833 (Curioni) & Turin 1836 \\
Naples 1833 & Vicenza 1836 \\
Madrid 1834 & Modena 1837 \\
Bologna 1834 & Pavia 1837 \\
Milan 1834 & Paris 1837 \\
Padua 1834 & Venice 1837 \\
Trieste 1834 & Ragusa 1838 \\
Venice 1834 & Venice 1838 \\
Rimini 1835 & Venice 1841 \\
Trieste 1835 & London 1841 \\
Brescia 1835 & Carpi 1842 \\
Venice 1835 & \\
\hline
\end{tabular}

Table 4b: Substitution history of Norma

Performances of Norma with Oroveso's aria substituted Performances of Norma with other substitutions

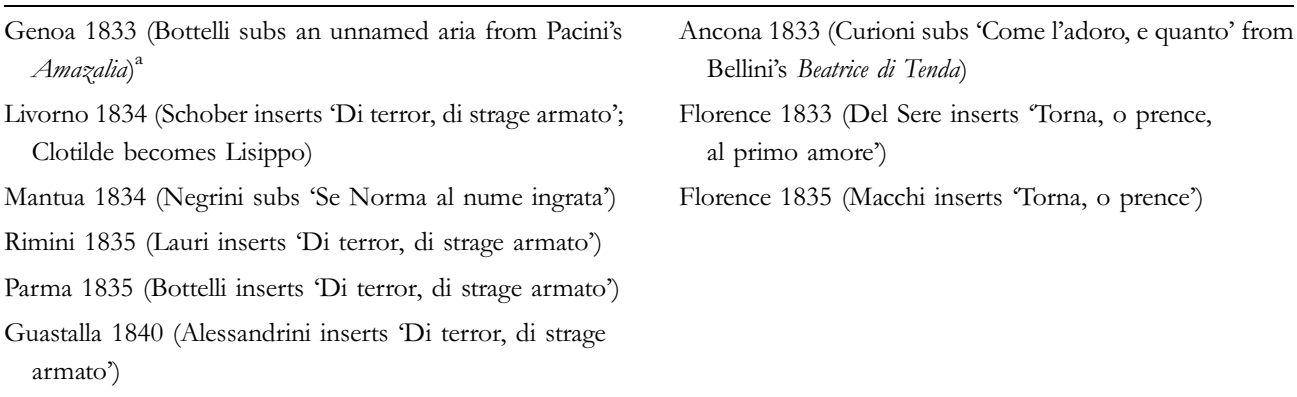

${ }^{a}$ Genoa 1833, Parma 1835 and Guastalla 1840 are not my findings, but cited in Poriss, 115. I do not have access to these libretti to confirm or expand upon these.

substitute arias to inflect an opera's narrative and strengthen their characters indicates that such strategic substitutions were viable across male-presenting roles.

The changeability of Oroveso's aria within an otherwise fixed text is usually explained with recourse to biography: the story goes that the original Oroveso, Vincenzo Negrini, suffered from a weak heart and could not withstand performing an extended scene, forcing Bellini to underwrite the role, leaving its Act II aria with only a brief cantabile and no cabaletta, a prime candidate for substitution. Scholars since Herbert Weinstock have accepted without question the story of Negrini's weak 
heart and its impact on Bellini's compositional process. ${ }^{48}$ It has escaped notice that this so-called 'bass' went on after Norma to specialise in roles such as Enrico (in Lucia di Lammermoor), Riccardo (in I puritani) and Filippo (in Beatrice di Tenda) - vocally demanding roles that in the 1830s were still labelled as basso cantante, but that were far more central to the plot than 'true' bass roles such as Lucia's Raimondo and I puritanis Giorgio. The first mention of Negrini in this new style appeared in Il Figaro in 1835, where he is described as 'basso-cantante, anche veramente baritono'. ${ }^{49}$ Negrini's career, then, fits the trajectory of the divergence of the basso cantante into its own category: the Italian baritone that also emerged out of this transition period, a dramatic type that would go on to feature prominently throughout Verdi's output. ${ }^{50}$ The oft-repeated stories of physical delicacy belie the agency Negrini exerted when he transformed Oroveso into a more forceful leader in his 1834 performances of Norma in Mantua.

In the second act of Norma, a group of druid warriors assemble in secret to ambush the Roman camp, anxious to spark their revolt after sustained placation from Norma. Oroveso enters with dire news: Pollione has been replaced with an even stronger leader, and their attack must be cancelled. In the libretto for the original 1831 production the druids ask:

Druidi: $\quad$ E Norma il sa? Di pace

È consigliera ancor?

Oroveso: Invan di Norma

La mente investigai; sembra che il Nume

Più non favelli a lei

(Chorus of Druids: Does Norma know this? / Does she still speak of peace? /

Oroveso: In vain I studied / Norma's thoughts; It appears that god / No longer speaks to her)

While these lines appear in the libretto for the premiere, Oroveso's last few words were never uttered on stage. Bellini's autograph confirms that this expression of distrust in Norma's ability to divine messages from the gods was excised during the compositional process and never set to music. ${ }^{51}$ The druids are left to respect the obscurity of Norma's divinations, still trusting that she is the sole conduit to their god. In the aria that follows, Oroveso and the druids reassure themselves: hide their true strength and disdain for now, and the eventual strike will be the more devastating.

48 Herbert Weinstock, Vincenzo Bellini: His Life and His Operas (New York, 1971), 488, n. 111. David R.B. Kimbell, Vincenzo Bellini: Norma (Cambridge, 1998), 13. Poriss, Changing the Score, 116. Stanley Sadie, ed., The Grove Book of Operas (Oxford, 2003), 435.

49 Il Figaro, vol. 3 no. 96 (2 December 1835).

50 On the baritone's development, see Marco Beghelli, Sulle tracce del baritono in Tra le note: studi di lessicologia musicale, ed. Fiamma Nicolodi and Paolo Trovato (Fiesole, 1996), 57-91.

51 Garland facsimile of the original autograph manuscript, Vincenzo Bellini, Norma, ed. Philip Gossett (New York, 1983). 
Ah! Del Tebro al giogo indegno

Fremo io pure, e all'armi anelo;

Ma nemico è sempre il cielo,

Ma consiglio è simular.

Divoriam in cor lo sdegno,

Tal che Roma estinto il creda:

Di verrà che desto ei rieda

Più tremendo a divampar.

(Ah! I too chafe beneath the Roman yoke / And long for battle; / But the heavens are against us, / We must pretend to be docile. / Let us keep our hatred in our heart, / Until the Romans think it dead: / The day will come when it will blaze forth / To burn with a more tremendous flame.)

This sequence of events, as laid out by Bellini, accords with the decision to excise the previously mentioned recitative lines. The aria's sentiment preserves Norma's authority over her community: the druids sheath their swords because their god, through Norma, has not given the command to attack.

Upon taking up the role of Oroveso for the second time, Negrini chose to play on this ambiguity in the power relations between Norma and the druids, upending the resigned acceptance of Bellini's brief aria. In place of 'Ah! Del Tebro', Negrini performed a scene of betrayal and recognition from Pacini's La schiava in Bagdad, rewriting the omitted sentiment of the deleted recitative lines and expanding it into a vengeance aria and cabaletta for Oroveso:

Negrini's substitution:

Se Norma al Nume ingrata

Scordò il dover l'onore

Da questo acciar svenata

Là sull'altar cadrà:

Il suo versato sangue

Il Nume placherà.

Oh! Come amai la perfida

Di sviscerato amore:

Ed or dovrò traffigerla!

Sento agghiacciarmi il cor;

Il duolo di quest'anima

Eterno oh Dio sarà!

[Cabaletta]

Su ti sveglia o mio coraggio

Si sopprima ogni altro affetto,

Parli sol m'avvampi in petto

\section{Pacini's original:}

Sugl'occhi suoi l'ingrata

Vedrà il rival traffitto,

Invano al suol prostrata

Mi chiederà pietà.

Bagnata di quel sangue

Anch'essa al suol cadrà.

In chi fidavi o credule!

Il più costante amore!

Come dispare rapida

La pace del tuo core!

Il duolo di quest'anima

Eterno oh Dio sarà!

Su ti sveglia o mio coraggio,

Si sopprima il vile affetto;

Parli sol, m'avvampi in petto 
La vendetta ed il furor.

Piombi poi sui Roman tutti

Il pugnal vendicator. ${ }^{52}$
La vendetta, ed il furor.

Piomberà su tutti i rei

Il pugnal vendicator. ${ }^{53}$

(Negrini's substitution: If Norma, ungrateful to god, / has forgotten duty and honor / vested in this bloody sword / on the altar she will fall: / Her spilled blood / will placate our god. / Oh, how I loved the treacherous one / with a tortured love: / and now I must kill her! / I feel a chill in my heart; / the sorrow of this soul, / Oh God, will be eternal! / Awaken, my courage; / suppress all other feelings, / in my chest is only / vengeance and fury. / Onto all the Romans / the avenging blow will fall.)

This replacement lends the scene and the entire role a new dramatic urgency. Negrini's Oroveso dares to brand Norma as ungrateful to their god and sacrifice her at the altar of Irminsul. As the druids' leader, Oroveso no longer blindly follows the selfish dictates of Norma, but questions her legitimacy and authority. Threatening to murder his own daughter, Oroveso rehearses the sensational threat of filicide that Norma herself had levelled against her children. This distrust precludes Norma's ability to remain in her community, further sealing her fate and intensifying the dilemmas that she will face in the opera's final scene. Choosing the music of Pacini's substitution also gave Negrini a multipartite scena as opposed to Bellini's brief cantabile, allowing his druid leader to sketch a dramatic arc. While Bellini's 'Ah! Del Tebro' builds on the melodic material of the preceding druid chorus 'Non parti?', the Pacini substitute stands apart musically, bringing Oroveso out from the homogenous fabric of his people. With this substitute aria, then, Negrini's Oroveso attains a more central role in the dramaturgy, stepping beyond the complacent resignation of Bellini's original bass role, and assuming authoritative, even violent masculinity.

Negrini's case shows that it was not just spurned tenors and late-career musicos who were revising masculine identity on stage. The basso cantante in the role of father and restrained political leader, never in the running for plot centrality in the first place, was also finding ways to exert himself as more significant within the drama, to refurbish dated dramaturgy through the theatrical conventions available to him.

While much of the music I have discussed here has been lost or scattered in archives across the globe, their poetic texts were preserved in the libretti printed for each run of performances. The very fact that theatres took such care to update and preserve these constantly mutating texts speaks to their importance in performance as the public text which audiences could follow during performance and refer to later at home to evoke memories of the evening. My inquiry, then, relies on the assumption that words and plot matter to the meanings and affects opera conveys. The importance of semantic, visual and dramatic parameters over vocal writing in

52 Vincenzo Bellini, Norma (Mantua, 1834).

53 Giovanni Pacini, La schiava in Bagdad (Turin, 1820). 
this inquiry is motivated by a crucial omission in Tacchinardi's polemic of 1833: instead of the rhetoric of predetermined vocal physiology - that women's voices could not possibly index a masculine body - he insisted on critiquing the musico's idiosyncratic dress, gesture and stage ethics, rather than their singing, as unmasculine. It was not the musico's voice that betrayed her as female, but rather the way her body misbehaved on stage. ${ }^{54}$ In the same manner, it was not the tenor's voice that confirmed him as male, but rather the way he constituted his character in narrative.

As a coda, let us briefly consider how a critic writing for the Gazzetta di Milano reacted to Giovanni David's unconvincing performance in the title role of Pacini's Alessandro nell'Indie in 1826:

The conqueror of all empires is only recognizable by his helmet and hauberk. We concede that the proud Macedonian, conquered by the charms of a fair enemy, spoke the language of love with the accent of passion; but [David's] swoons, lazy gestures, and mannered movements are not for the temper of that fierce spirit. ${ }^{55}$

The critic points to David's dress and gesture as parameters for success in masculineheroic portrayal; comportment of the visible body in action, rather than singing, is the primary index of gender type. The body itself accrues gender through dramatic textualisation, rather than the knee-jerk recognition of a masculine body within the tenor voice. In other words, the notion of a gendered vocalic body has a history: in an era before a singer's individuality was expressed in timbre, the voice as it sings may have produced no bodies at all. ${ }^{56}$

For performers such as Tacchinardi, stage masculinity was far from an alwaysalready maleness that would eventually erupt into the world at Duprez's mythic high $\mathrm{C}$, but rather a textual practice of character posturing and narrative authorship. Before he could rely on the natural physiology of his male body, the male performer exchanged stasis for action - the difference between praise and demand, retreat and attack. It should perhaps trouble us that the markers of decisive action in all these instances of substitution entail the instalment of masculine power over their feminine counterparts. Eve Sedgwick's classic model of triangulation would suggest that the masculine rivalries in Sacerdotessa and La donna del lago appear as a relation of male homosociality expressed through acts of violence and clemency. ${ }^{57}$ Romilda and Elena exist less as autonomous actors than symbolic property for negotiating patriarchal power - when demanded, they appear; their fates are handed down as aftereffects of political arbitration, their bonds of love are thin veneers for the bonds of nations. This privileging of the male gaze and of relations between men as a means of diagnosis and control (critics see Tacchinardi, Tacchinardi sees musicos, Tacchinardi

54 As late as 1830, the surgeon Francesco Bennati still considered 'tenori-contraltini' to be a single anatomical category. See Davies, Romantic Anatomies, 22.

55 Gazzetta di Milano (29 December 1826), 1431-2. As cited and translated in Hadlock, 'Different Masculinities', 208. Pacini writes in his memoir that David was adamant it was the composer's music for Alessandro that was lacking, and demanded Pacini rewrite the role's cavatina five different times, to no avail in pleasing the public, 48-9.

56 Stephen Connor, Dumbstruck (Oxford, 2000), 35-6.

57 See Eve Sedgwick, Between Men (New York, 1985). 
sees prima donnas) would seem to render irrelevant musicology's familiar redemptive move of hearing women's voices. Tacchinardi's choice of substitute arias endowed the tenor hero with the agency to demand the prima donna's presence under his gaze, a narrative enactment of control over her whereabouts that, like Wagner's acts of conjuration through narrative, are immediately fulfilled. ${ }^{58}$ Negrini's newfound authority over the text of Norma is one with, and indistinguishable from, Oroveso's newfound agency to commit violence upon his daughter. In their bid to move from representation to presentation, and from appearance to action, male performers codified a new stage masculinity through the stylised repetition of acts: acts in which the masculine hero used aria substitution to exert narrative control over women's bodies.

PARKORN WANGPAIBOONKIT is a PhD candidate in Musicology at the University of California, Berkeley. His dissertation project 'Sounding Civilization: Race and Sovereignty in the Imperial Opera of Siam, 1870-1910' examines how the localisation of Western art practices in late nineteenth-century Siam, particularly ideas about race and the singing voice, served as a discursive site for negotiating ethnological imperialism across the colonial modern. His work is supported by the Howard Mayer Brown Fellowship from the American Musicological Society.

58 I am referring to scenes such as Senta's ballad and Elsa's dream narrative, in which the soprano's half-demented yearning for the tenor immediately summons his presence. For Tacchinardi, however, the masculine demand is clear-headed. See Carolyn Abbate, Unsung Voices (Princeton, 1991), 85-96. 